\title{
THIODIA TORRIDANA (LEDERER, 1859) (LEPIDOPTERA: TORTRICIDAE) A NEW SPECIES FOR THE CROATIAN FAUNA
}

\author{
Toni Koren \\ Croatian Herpetological Society - Hyla, Lipovac I 7, HR-10000 Zagreb, Croatia, \\ (e-mail: koren.toni1@gmail.com)
}

Koren, T.: Thiodia torridana (Lederer, 1859) (Lepidoptera: Tortricidae) a new species for the Croatian fauna. Nat. Croat., Vol. 25, No. 1, 163-164, 2016, Zagreb.

On June $12^{\text {th }}, 2015$ one specimen of Thiodia torridana (Lederer, 1859) was collected at Kozja Draga, Lika region, Croatia. This species is known from most countries in Europe, but records from the Balkans are missing. This is the first record of this species for the Croatian fauna and the closest records are from Slovenia and Hungary.

Key words: moths, tortrix moths, distribution, Kozja Draga, Lika

Koren, T.: Thiodia torridana (Lederer, 1859) (Lepidoptera: Tortricidae) nova vrsta u fauni Hrvatske. Nat. Croat., Vol. 25, No. 1, 163-164, 2016, Zagreb.

Dana 12. lipnja 2015. jedan primjerak vrste Thiodia torridana (Lederer, 1859) sakupljen je na lokalitetu Kozja Draga (Lika, Hrvatska). Ova vrsta poznata je iz većine država Europe, no podatci iz država Balkana nedostaju. Ovo je prvi nalaz te vrste za faunu Hrvatske, dok su najbliži poznati nalazi iz Slovenije i Mađarske.

Ključne riječi: noćni leptiri, savijači, distribucija, Kozja Draga, Lika

The moth fauna of Croatia is in general insufficiently known (with the exception of the fauna of Krk; HABELER, 2008), and this is particularly true for most Microlepidoptera families. Almost any survey of Microlepidoptera in any part of the country yields new country records (e.g. TREMATERRA \& BALDIZZONE, 2004; ŠUMPICH, 2013) and in some cases records of newly described species (Altenia elsneriella Huemer \& Karsholt, 1999, Scrobipalpa tokari Huemer \& Karsholt, 2010 or Neurothaumasia tenuipennella Gaedike, 2011).

The surveyed area of Lika is one of the most poorly studied regions of Croatia, especially in terms of moth diversity. The only more extensive survey was done on the family Noctuidae, for which 83 species were recorded (KučInIć, 1992). During a field trip to the Lika region on the foothills of Mt Plješevica, Kozja draga (N: 44.56016173, E: $15.83254974^{\circ}$, July $28^{\text {th }} 2015$ ) a single specimen of Thiodia torridana (Lederer 1859) was collected, which represents the first record for Croatia (Fig. 1). The habitat on the collection locality included karstic grassland bordered with beech forest. The voucher specimen was identified using RAzowsKi $(2002,2003)$ and deposited in the author's collection.

Thiodia torridana is distributed in larger parts of Europe, Transcaucasia, Asia Minor, Kazakhstan, Turkmenia and Russia. The closest known records originats from Slovenia (Lesar \& Habeler, 2005; Jež et al., 2015) and Hungary (PAstorális, 2010). As the literature covering European Tortricidae is scante, the available sources were checked to confirm this as the first record of ths species in Croatia (RAzowsKI, 2002, 2003; FAUNA EuropaeA, 2016). As no checklists existneither for Croatia, Serbianor for Montenegro, its 


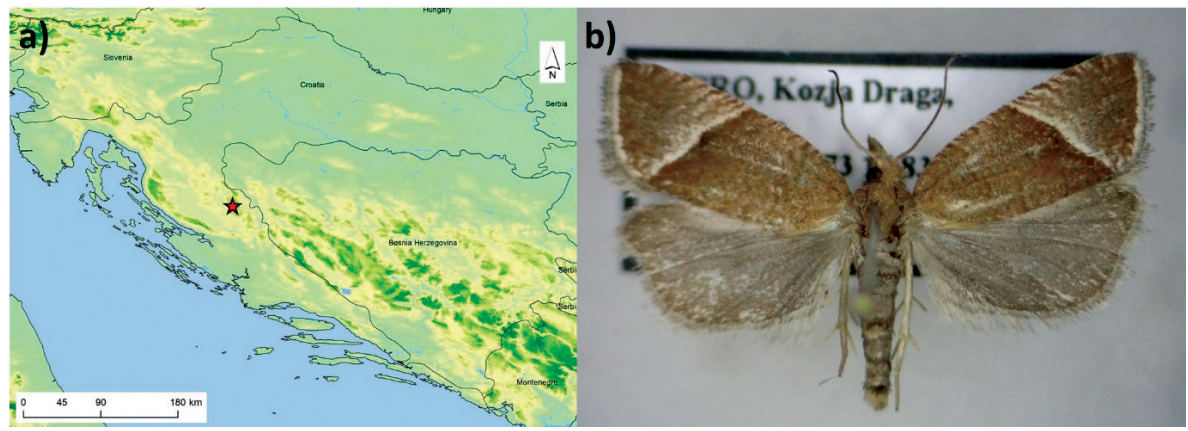

Fig. 1. a) Location of Kozja Draga, b) T. torridana from the locality.

occurrence in these countries can only be gleamed from FAuna EuropaEa (2016). No records exist from Bosnia \& Herzegovina (LeLo, 2004). Accordingly, since this species is still not recorded in other Balkan countries, dit is at the moment the southernmost from the Balkan Peninsula.

\section{ACKNOWLEDGMENTS}

I am grateful to Domen Trkov for his help and company during the field survey, and to Stanislav Gomboc for the confirmation of the correct identification.

Received March 2, 2016

\section{REFERENCES}

Fauna Europaea, 2016: Fauna Europaea version 2.5. Web Service available online at http://www.faunaeur. org (accessed on 10.2.2015).

Gaedike, R., 2011: New and poorly known Tineidae from the Western Palaearctic (Lepidoptera). Beitr. Entomol. 61, 357-370.

Habeler, H., 2008[2003]: Die Schmetterlinge der Adria-Insel Krk. Eine ökofaunistische Studie. Esperiana - Buchreihe zur Entomologie, 221 pp.

Huemer, P. \& Karsholt, O., 1999: Gelechiidae I (Gelechiinae: Teleiodini, Gelechiini). In: Huemer, P., Karsholt, O. \& L. Lyneborg (Hrsg.): Microlepidoptera of Europe 3. Stenstrup, Apollo Books, 356 pp.

Huemer, P. \& Karsholt, O., 2010: Microlepidoptera of Europe. Volume 6. Gelechiidae II (Gelechiinae: Gnorimoschemini). Stenstrup, Apollo Books, 586 pp.

Jež, M., ZAKŠEK, V., Štanta, R., ZADravec, B. \& Verovnik, R., 2015: Favna nočnih metuljev (Lepidoptera) na izbranih osvetljenih cerkvah v Sloveniji. (SL) Moth fauna (Lepidoptera) at selected illuminated churches in Slovenia. Nat. Slo. 17(2), 17-45.

Kučinić, M., 1992: The Noctuidae (Insecta, Lepidoptera) of Lička Plješevica Mountain (Croatia). Nat. Cro. $1,71-80$.

Lesar, T. \& Habeler, H., 2005: Beitrag zur Kenntnis der Kleinschmetterlinge (Microlepidoptera) von Štajersko und Koroško in Slowenien. Nat. Slo. 7(2), 3-127.

Lelo, S., 2004: Revizija Rebelovog popisa leptira Bosne i Hercegovine. CORON'S d.o.o., Sarajevo, 295 pp.

Pastorális, G., 2010: A checklist of Microlepidoptera (Lepidoptera) occurred in the territory of Hungary (1.4). e-Acta Nat. Pannon. 1(1), 89-170.

RAzowsKI, J., 2002: Tortricidae of Europe. Vol. 1: Tortricinae and Chlidanotinae. Franisek Slamka, Bratislava, $247 \mathrm{pp}$.

RAzowski, J., 2003: Tortricidae (Lepidoptera) of Europe, Vol. 2: Olethreutinae. Franisek Slamka, Bratislava, $301 \mathrm{pp}$.

Šumpich, J., 2013: Faunistic records of some Microlepidoptera from Croatia. Entomol. Croat. 17(1-4), 13-33.

Trematerra, P. \& Baldizzone, G., 2004: Records of Lepidoptera Tortricidae from Krk island (Croatia). Entomol. Croat. 8, 25-44. 